\title{
Erratum to: Barriers and facilitators to the implementation of orthodontic mini implants in clinical practice: a systematic review
}

Reint Meursinge Reynders ${ }^{1,2^{*}}$, Laura Ronchi ${ }^{2}$, Luisa Ladu ${ }^{2}$, Nicola Di Girolamo ${ }^{3}$, Jan de Lange ${ }^{4}$, Nia Roberts ${ }^{5}$ and Sharon Mickan ${ }^{6}$

\section{Erratum}

After publication of the original article [1], the authors noticed that one of their correction requests had been missed:

In Table 8, column "Prevalence of the barrier", a superscripted "a" was included next to the " $5 \%$ " and "1 \%" prevalence data. These "a"s should have been removed. This is now corrected in the original article and also shown in the below table. We apologise for any inconvenience caused by this error.

\footnotetext{
Author details

${ }^{1}$ Department of Oral and Maxillofacial Surgery, Academic Medical Center, University of Amsterdam, Meibergdreef 9, 1105, AZ, Amsterdam, The Netherlands. ${ }^{2}$ Via Matteo Bandello 15, 20123 Milan, Italy. ${ }^{3}$ Department of Veterinary Sciences, University of Bologna, Via Tolara di Sopra 50, 40064 Ozzano dell'Emilia, BO, Italy. ${ }^{4}$ Department of Oral and Maxillofacial Surgery, Academic Medical Center and Academisch Centrum Tandheelkunde Amsterdam (ACTA), University of Amsterdam, Meibergdreef 9, 1105, AZ, Amsterdam, The Netherlands. ${ }^{5}$ Bodleian Health Care libraries, Cairns Library Level 3, John Radcliffe Hospital, University of Oxford, Oxford OX3 9DU, UK. ${ }^{6}$ Department of Allied Health, Gold Coast Health and Griffith University, Queensland, QLD 4222, Australia.
}

Received: 17 October 2016 Accepted: 17 October 2016

Published online: 25 October 2016

\section{References}

1. Meursinge Reynders R, Ronchi L, Ladu L, Di Girolamo N, de Lange J, Roberts $\mathrm{N}$, Mickan S. Barriers and facilitators to the implementation of orthodontic mini implants in clinical practice: a systematic review. Systematic Reviews. 2016;5:163. doi:10.1186/s13643-016-0336-z.

\footnotetext{
* Correspondence: reyndersmail@gmail.com

'Department of Oral and Maxillofacial Surgery, Academic Medical Center,

University of Amsterdam, Meibergdreef 9, 1105, AZ, Amsterdam, The Netherlands

${ }^{2}$ Via Matteo Bandello 15, 20123 Milan, Italy

Full list of author information is available at the end of the article
} 
Table 8 Barriers and facilitators to the implementation of $\mathrm{OMIs}^{\mathrm{a}}$

\begin{tabular}{|c|c|c|c|c|}
\hline Study & Number & Facilitators & Stakeholders & $\begin{array}{l}\text { Prevalence of the } \\
\text { facilitator }\end{array}$ \\
\hline $\begin{array}{l}\text { Zawawi } \\
2014[85]\end{array}$ & 1 & $\begin{array}{l}\text { Agree to have OMls to facilitate tooth } \\
\text { movement and reduce treatment time }\end{array}$ & 165 orthodontic patients & $82.4 \%(136 / 165)$ \\
\hline $\begin{array}{l}\text { Zawawi } \\
2014[85]\end{array}$ & 2 & Choosing OMls over extractions & 165 orthodontic patients & $86.7 \%(143 / 165)$ \\
\hline \multirow[t]{2}{*}{$\begin{array}{l}\text { Zawawi } \\
\text { 2014[85] }\end{array}$} & 3 & $\begin{array}{l}\text { Agree to have OMls when they were the } \\
\text { only option }\end{array}$ & 165 orthodontic patients & $90.9 \%(150 / 165)$ \\
\hline & & Barriers & Stakeholders & $\begin{array}{l}\text { Prevalence of the } \\
\text { barrier }\end{array}$ \\
\hline $\begin{array}{l}\text { Zawawi } \\
2014[85] \\
\end{array}$ & 4 & Costs & 165 orthodontic patients & $65.5 \%(108 / 165)$ \\
\hline $\begin{array}{l}\text { Meeran } \\
2012[8]\end{array}$ & 5 & Lack of training & $\begin{array}{l}952 \text { orthodontic clinicians that } \\
\text { were non-users of OMls }\end{array}$ & $67 \%(638 / 952)$ \\
\hline $\begin{array}{l}\text { Meeran } \\
2012[8]\end{array}$ & $6^{b}$ & $\begin{array}{l}\text { Fear of risk factors like root damage and } \\
\text { infection }\end{array}$ & $\begin{array}{l}952 \text { orthodontic clinicians that } \\
\text { were non-users of OMls }\end{array}$ & $54 \%(514 / 952)$ \\
\hline $\begin{array}{l}\text { Meeran } \\
2012[8]\end{array}$ & 7 & Patient refusal to accept OMls & $\begin{array}{l}952 \text { orthodontic clinicians that } \\
\text { were non-users of OMls }\end{array}$ & $29 \%(276 / 952)$ \\
\hline $\begin{array}{l}\text { Meeran } \\
2012[8]\end{array}$ & $8^{b}$ & $\begin{array}{l}\text { Did not encounter any case requiring } \\
\text { OMls }\end{array}$ & $\begin{array}{l}952 \text { orthodontic clinicians that } \\
\text { were non-users of OMls }\end{array}$ & $14 \%(133 / 952)$ \\
\hline $\begin{array}{l}\text { Meeran } \\
2012[8]\end{array}$ & 9 & $\begin{array}{l}\text { Prefer traditional or conventional } \\
\text { methods of treatment without } \\
\text { unnecessary invasive procedures }\end{array}$ & $\begin{array}{l}952 \text { orthodontic clinicians that } \\
\text { were non-users of OMls }\end{array}$ & $5 \%(48 / 952)$ \\
\hline $\begin{array}{l}\text { Meeran } \\
2012[8]\end{array}$ & $10^{b}$ & Cost factor & $\begin{array}{l}952 \text { orthodontic clinicians that } \\
\text { were non-users of OMls }\end{array}$ & $1 \%(10 / 952)$ \\
\hline Bock 2015[5] & $11^{\circ}$ & (Almost) no suitable indications & $\begin{array}{l}345^{\mathrm{a}} \text { orthodontic clinicians } \\
\text { that were non-users of OMls }\end{array}$ & $51.0 \%(176 / 345)$ \\
\hline Bock 2015[5] & 12 & $\begin{array}{l}\text { Skeptical about additional benefit of } \\
\text { OMls }\end{array}$ & $\begin{array}{l}345^{\mathrm{a}} \text { orthodontic clinicians } \\
\text { that were non-users of OMls }\end{array}$ & $33.3 \%(115 / 345)$ \\
\hline Bock 2015[5] & 13 & $\begin{array}{l}\text { Skeptical about success/failure rates of } \\
\text { OMls }\end{array}$ & $\begin{array}{l}345^{a} \text { orthodontic clinicians } \\
\text { that were non-users of OMls }\end{array}$ & $56.2 \%(194 / 345)$ \\
\hline Bock 2015[5] & 14 & $\begin{array}{l}\text { Insertion/surgery too complex or time- } \\
\text { consuming }\end{array}$ & $\begin{array}{l}345^{\mathrm{a}} \text { orthodontic clinicians } \\
\text { that were non-users of OMls }\end{array}$ & $32.5 \%(112 / 345)$ \\
\hline Bock 2015[5] & $15^{\circ}$ & $\begin{array}{l}\text { Concerned about the complication/ } \\
\text { injury rate of OMls }\end{array}$ & $\begin{array}{l}345^{3} \text { orthodontic clinicians } \\
\text { that were non-users of OMls }\end{array}$ & $24.3 \%(84 / 345)$ \\
\hline Bock 2015[5] & 16 & No appropriate surgeon nearby & $\begin{array}{l}345^{\mathrm{a}} \text { orthodontic clinicians } \\
\text { that were non-users of OMls }\end{array}$ & $32.8 \%(113 / 345)$ \\
\hline Bock 2015[5] & $17^{b}$ & Insertion/surgery too expensive & $\begin{array}{l}345^{3} \text { orthodontic clinicians } \\
\text { that were non-users of OMls }\end{array}$ & $9.6 \%(33 / 345)$ \\
\hline
\end{tabular}

Items in black-type face represent those of the published manuscript. Items in red-type face represent those obtained through contacting the authors of the pertinent manuscript

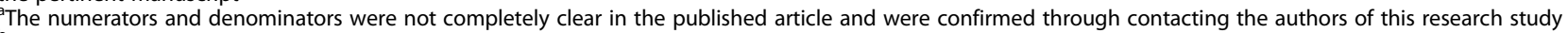
${ }^{\mathrm{b}}$ Barriers 6 and 15, 8 and 11 , and 10 and 17 overlap 